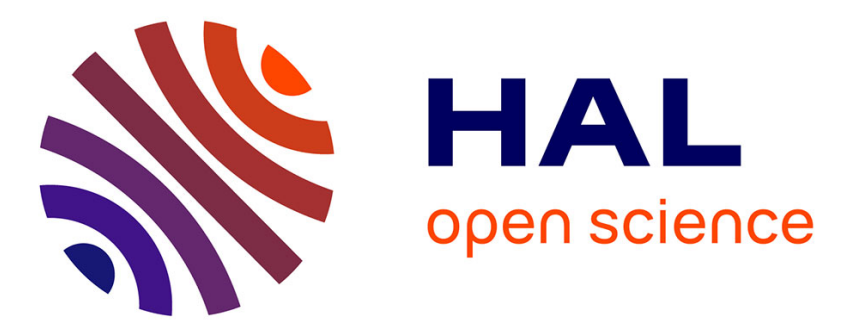

\title{
New authoring frameworks for integrating collaborative learning technologies
}

\author{
Turadg Aleahmad, James Slotta, Wouter van Joolingen
}

\section{To cite this version:}

Turadg Aleahmad, James Slotta, Wouter van Joolingen. New authoring frameworks for integrating collaborative learning technologies. Computer Supported Collaborative Learning (CSCL 2007), July 18 2007, New Brunswick, United States, 2007, New Brunswick, United States. 2 p. hal-00190042

\section{HAL Id: hal-00190042 \\ https://telearn.archives-ouvertes.fr/hal-00190042}

Submitted on 23 Nov 2007

HAL is a multi-disciplinary open access archive for the deposit and dissemination of scientific research documents, whether they are published or not. The documents may come from teaching and research institutions in France or abroad, or from public or private research centers.
L'archive ouverte pluridisciplinaire HAL, est destinée au dépôt et à la diffusion de documents scientifiques de niveau recherche, publiés ou non, émanant des établissements d'enseignement et de recherche français ou étrangers, des laboratoires publics ou privés. 


\title{
Workshop held at the Computer Supported Collaborative Learning Conference. New Brunswick, NJ \\ New authoring frameworks for integrating collaborative learning technologies
}

\author{
Turadg Aleahmad, Carnegie Mellon University, HCII, 5000 Forbes Ave, Pittsburgh, PA 15213 \\ Jim Slotta, Canada Research Chair in Education and Technology, OISE, University of Toronto, \\ 252 Bloor St. W. \#11-268, Toronto, ON. M5S-1V6 Canada \\ Wouter van Joolingen, University of Twente, Faculty of Behavioral Sciences, \\ P.O. Box 217, 7500 AE ENSCHEDE, Netherlands, w.r.vanjoolingen@utwente.nl
}

\begin{abstract}
This workshopis intended for CSCL researchers and/or their technologists who are interested in designing and then actually creating rich, interactive learning materials in a technology-enhanced environment. The workshop will present the work of two complementary approaches to the design of environments for collaborative, productive and open ended learning, such as collaborative inquiry learning and learning by design. Participants bring in their own issues and work on the design of learning environments in a hands-on experience.
\end{abstract}

\section{Theme and goals}

This workshop offers participants the chance for hands-on experience with two recent authoring frameworks for technology-enhanced CSCL activities. We will describe how to adopt these environments as sustainable research platforms, and discuss the vision of a community of developers. We address the issues of interoperability, re-use, open source and open content, as well as recent trends toward standardization (e.g., SCORM or IMS/LD). We invite participants to bring with them: A description of a CSCL activity that they would like to develop; a specific CSCL tool or technology that they would like to integrate within a larger framework; an idea for a new tool or feature that they would like to create; research questions they would like to address. We will discuss key issues and present demonstrations in the morning, followed by direct hands-on work by individual participants, in consultation with workshop leaders.

The leaders of this workshop have a wealth of experience in the development of technology frameworks for CSCL activities. Jim Slotta $(2000,2004)$ led the design of the WISE learning environment (http://wise.berkeley.edu $\left.{ }^{\mathrm{a}}\right)$ - a Web-based system that allows researchers to develop interactive inquiry projects, delivers the content to students, collects all data, and supports teachers as they implement the materials in their classrooms. Numerous research labs now use WISE as a research platform for the development and delivery of experimental materials. Wouter Van Joolingen and his colleagues (van Joolingen \& de Jong, 2003; van Joolingen, de Jong, Lazonder, Savelsbergh, \& Manlove, 2005) have developed Simquest (http://www.simquest.nl ${ }^{\text {बa }}$ ), which guides learners through a structured inquiry process, and more recently, Co-Lab (Collaborative Laboratories - http://www.co-lab.nl ${ }^{3}$ ), which allows learners to collaboratively set up a study of the climate in a greenhouse, design experiments, process the data from these experiments, develop models and theories, and report about their work. Turadg Aleahmad (Slotta \& Aleahmad, in press) has led the design of the new Scalable Architecture for Interactive Learning (SAIL, http://sail.sourceforge.net ${ }^{\text {sas }}$ ), a framework for developing pedagogical software, and Pas, an application suite for collaborative inquiry learning. We will demonstrate our latest innovations, discuss the most pressing topics related to technology frameworks, and consult with participants to help them take forward strides in developing their own materials or make decisions about research platforms.

This new generation of open software allows a greater degree of innovation and enables a wider range of pedagogical scenarios (Slotta \& Aleahmad, in press). SAIL is Java component framework that enabled the rapid development of Pas, which like WISE includes everything required for researchers to adopt as a stand alone research platform. All SAIL-based objects can be shared amongst any SAIL-based platform, allowing the development of an exchange community. The hope is that this will encourage a community of open source development, enabling rapid evolution and exchange amongst researchers. Another framework is CIEL: Collaborative Inquiry and Experiential Learning (http://www.cielproject.eu ${ }^{\star}$ ), which enables collaborative real time environments to interoperate with other learning technologies.

These resources are available to CSCL researchers right now. Indeed, most labs that were using the WISE system are now adopting their own SAIL-based platforms, and will go forward with separate but interoperable systems. 
CIEL has enabled the integration of the Co-Lab software with a suite of tools called Cool Modes developed by researchers in Duisburg-EssenUniversity (Pinkwart, 2003; Pinkwart, Hoppe, Bollen, \& Fuhlrott, 2002). The goal of this workshop is to offer such resources to the wider community, discuss a range of issues including interoperability, scalability and sustainability, and engage participants in hands on design and authoring activities.

\section{Outcomes and contributions}

- In advance of the workshop, each participant will complete a wiki template concerning: their topic of research; specific scenarios concerning the kinds of learning materials or tools they would like to develop; their questions with regard to interoperability; their personal goals for the workshop.

- In advance of the workshop, these participant submissions will by synthesis by the leaders into a small number of discussion categories for the workshop. This and the discussion at the workshop will remain in the wiki for future reference and discussion.

- We will offer each participant open access to all the technology, including them in a community (ENCORE, http://www.encorewiki.org ${ }^{2}$ ) that will provide ongoing support. We hope for participants who have the intention of adopting these systems, and will work with them to develop a clear understanding of their next steps, as well as a sense of active membership in a community of peers.

- For each participant, the workshop will contribute distinct, individuated progress in their thinking about the design, development and implementation of CSCL activities using these new frameworks.

\section{Format}

- Designed for 5-20 participants.

- In the morning, we will have introductions, demos and discussion. One goal of discussion is to address common issues relating to technology frameworks (e.g., standards, re-use, learning content management, etc). Another is to develop shared views on the architectures for collaborative inquiry learning, expressed in a shared collection/classification of learning objects and tools. We would also review the ideas from the pre-workshop wiki, examining the scenarios of inquiry learning, etc.

- In the afternoon there will be hands-on authoring, design, and question and answer consultation, giving each participant a direct experience of progress, including "next steps" for their participation.

- The workshop will conclude with a synthesis discussion and presentation of ENCORE.

\section{References}

Pinkwart, N. (2003). A plug-in architecture for graph based collaborative modeling systems. In H. U. Hoppe, F. Verdejo \& J. Kay (Eds.), Proceedings of the 11th Conference on Artificial Intelligence in Education, (pp. 535-536). Amsterdam: IOS press.

Pinkwart, N., Hoppe, H. U., Bollen, L., \& Fuhlrott, E. (2002). Group-oriented modelling tools with heterogeneous semantics. In Lecture Notes in Computer Science, Proceedings of ITS 2002 Biarritz (F), June 2002 (pp. 21 30). Berlin: Springer Verlag.

Slotta, J. D., \& Aleahmad, T. (in press). The Scalable Architecture for Interactive Learning (SAIL). International Journal of Science Edcucation.

van Joolingen, W. R., \& de Jong, T. (2003). SimQuest: Authoring educational simulations. In T. Murray, S. Blessing \& S. Ainsworth (Eds.), Authoring tools for advanced technology educational software: Toward cost-effective production of adaptive, interactive, and intelligent educational software (pp. 1-31). Dordrecht: Kluwer Academic Publishers.

van Joolingen, W. R., de Jong, T., Lazonder, A. W., Savelsbergh, E. R., \& Manlove, S. (2005). Co-Lab: research and development of an online learning environment for collaborative scientific discovery learning. Computers in Human Behavior, 21(4), 671-688 